\title{
Nutritional status of adult Tuberculosis patients in Burdwan municipality area of West Bengal
}

Azharuddin Mollah ${ }^{1}$, Prabha Shrivastava ${ }^{2}$, Dilip Kr Das ${ }^{3}$, Soumalya Ray ${ }^{4}$

${ }^{1}$ Senior Resident, Department of Community Medicine, Burdwan Medical College and Hospital, Burdwan, West Bengal;

${ }^{2}$ Associate Professor, Department of Community Medicine, Burdwan Medical College and Hospital, Burdwan, West Bengal;

${ }^{3}$ Professor and Head, Department of Community Medicine, Burdwan Medical College and Hospital, Burdwan, West Bengal;

${ }^{4}$ Assistant Professor, Department of Community Medicine, Burdwan Medical College and Hospital, Burdwan, West Bengal

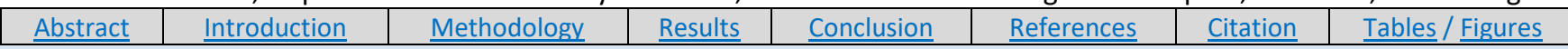

\section{Corresponding Author}

Dr. Soumalya Ray, Department of Community Medicine, Burdwan Medical College and Hospital, Burdwan, West Bengal. PIN - 713104

E Mail ID: drsoumalya@gmail.com

\section{Citation}

Mollah A, Srivastava P, Das DK, Ray S. Nutritional status of adult Tuberculosis patients in Burdwan municipality area of West Bengal. Indian J Comm Health. 2020;32(2):438-443.

Source of Funding: Nil Conflict of Interest: None declared

\section{Article Cycle}

Received: 07/06/2020; Revision: 13/06/2020; Accepted: 19/06/2020; Published: 30/06/2020

This work is licensed under a Creative Commons Attribution 4.0 International License.

\section{Abstract}

Background: Nutritional status of a Tuberculosis (TB) patient plays a role in disease manifestation. Aims \& Objective: To assess the nutritional status of adult tuberculosis patients under intensive phase of treatment. Settings and Design: A descriptive study with cross-sectional design was conducted at Burdwan Municipality of West Bengal. Methods and Material: In this study, TB patients aged 18 years and above receiving intensive phase of treatment, registered in the Tuberculosis units in the months of October-December, 2018 and residing in the municipality were approached. Nutritional status was evaluated through two approaches - dietary intake by twenty-four hours recall method and anthropometric status by measuring weight, height, BMI and MUAC. Data were analysed using SPSS v20. Results: Out of 113 study subjects, under-nutrition was present in $61.9 \%$ and inappropriate MUAC was observed in $68.1 \%$. Interestingly, intake of Cereals and Millets among food groups was found to be deficient. The adjusted odds ratio for having under-nutrition among new cases compared to previously treated was 0.16 (0.33-0.82). Conclusions: For combating protein energy malnutrition in TB patients, emphasis should be given on balanced diet intake.

\section{Keywords}

Nutrition Assessment; Nutritional Status; Tuberculosis; Diet Surveys; Adults

\section{Introduction}

Tuberculosis (TB) is a scourge of the mankind and this is in spite of it being a preventable and curable disease. Nutritional status of an individual, specifically undernutrition, plays a very important role in the pathophysiology of tuberculosis. In a population level study, Bhargava et al. reported that under-nutrition contributed to $55 \%$ of annual TB incidence; and, thus provided the causal link between under-nutrition and active TB (1). Under-nutrition increases the risk of severity of disease, death, toxicity and mal-absorption of drug and relapse after cure $(2,3)$. Nutritional support breaks the vicious cycle of under-nutrition and worsening the disease condition. World Health Organization (WHO) released operational guidelines for nutritional care and support of patients with TB in 2013 (4) recommending nutritional assessment, counseling and support as an integral part of patient management. In accordance with the WHO guideline, Government of India has advocated a guiding document on the implementation of nutritional support for TB patients (5), which described nutritional assessment to include Clinical assessment consisting of a nutrition-oriented history and a nutrition oriented examination, Anthropometric assessment and Dietary and laboratory assessment (wherever feasible and appropriate). Information about nutritional status in terms of dietary assessment and anthropometric measurement is lacking in this part of the country. In this context, the current study was planned to evaluate the nutritional status of adult TB patients which eventually would be helpful in implementation of appropriate 
nutritional support and further strengthening the ongoing national programme in the country.

\section{Aims \& Objectives}

1. To evaluate the nutritional status by anthropometric measurements of adult TB patients residing in an urban area of Purba Bardhaman district.

2. To assess the dietary intake of adult TB patients under intensive phase of treatment residing in an urban area of Purba Bardhaman district.

3. To find out the association, if any, between basic background characteristics and nutritional status of the study participants.

\section{Material \& Methods}

This descriptive type of observational study with crosssectional design was conducted at Burdwan Municipality, Purba Bardhaman district, West Bengal. The study population was all the consenting TB individuals aged above 18 years and under intensive phase of DOTS regime, registered in the Tuberculosis unit (TU) during the study period - i.e., within the months of October-December, 2018 and residing in the Burdwan municipality. Critically ill patients, pregnant women and subjects who were not available after three repeated attempts were excluded.

According to a study done in rural central India, undernutrition was found in $53 \%$ of patients with TB (2). Considering this prevalence of $53 \%$ (p) with $5 \%$ alpha error, $10 \%$ relative error and finally applying the Finite population correction for a total population of 121 , the minimum sample size came to 92 . Tuberculosis being a disease associated with social stigma, $25 \%$ non-response rate was assumed. Thus the required sample size was 115 . The list of patients currently diagnosed with tuberculosis (both new cases and previously treated) under intensive phase of DOTS regime, residing in the municipality area and also registered in the study period was obtained, and selected from the registers by simple random sampling. Data were collected after ethical approval of the synopsis from Institutional Ethics Committee of the Burdwan Medical College \& Hospital. Prior to data collection, the respective health authorities were intimated about the purpose of the study; their permission and cooperation was sought. Informed consent was obtained from each and every study subjects and after being assured about the confidentiality of the information. The data was collected at a mutually convenient place using a predesigned and pre-tested schedule, relevant records and registers, measuring tape and weighing machine. The dietary history regarding intake of total energy, carbohydrate, fat and protein was assessed by interviewing the study subjects using twenty-four hours dietary recall method quantified by portion size; followed by anthropometric measurement of height (centimetre), weight (kilogram), and Mid Upper Arm Circumference (MUAC) in centimetre. Adequacy of dietary intake was assessed using the portion method based on the guidelines available from National Institute of Nutrition (NIN) (6). Under-nutrition was defined by BMI of less than $18.5 \mathrm{~kg} /$ meter $^{2}$, and MUAC less than $23 \mathrm{~cm}$ in male \& less than $22 \mathrm{~cm}$ in female was taken as inappropriate.

Data were organized and presented applying the principles of descriptive statistics in the form of tables and diagrams as well as calculating proportions and analyzed using Statistical Package for the Social Sciences (IBM SPSS statistics for Windows, version 20.0. Armonk, New York (US): IBM Corp. 2011). To predict presence of undernutrition, multivariable logistic regression analysis model was made with under-nutrition as the dependent variable. Goodness of fit and pseudo R square value of the model was reported; $p$ value $\leq 0.05$ was considered as statistically significant.

\section{Results}

There were a total of 121 patients aged 18 years and above who were registered in Tuberculosis units of Burdwan Municipality. 115 individuals (required sample size) were selected through simple random sampling from this list. Two individuals did not agree to participate in the study. Thus, 113 subjects participated in this study. It was observed that, out of 113 study subjects, the mean age of the participants was 40.74 years (SD \pm 14.390 ). Undernutrition was present in $61.9 \%$ of the study subjects and inappropriate MUAC was observed in $68.1 \%$ of subjects (Table 1). The mean \pm SD MUAC in males was $22.23 \pm 1.76$ $\mathrm{cm}$ and in female was $22.11 \pm 1.90 \mathrm{~cm}$.

Dietary assessment revealed that total energy intake in last 24 hours cycle was deficient in $86.7 \%$ participants, whereas, protein and visible fat was adequately consumed by $72.6 \%$ and $63.7 \%$ participants respectively (Table 2).

Multivariable logistic regression analysis predicting the outcome of under nutrition found that only new cases were having significantly lesser odds of having under nutrition than previously treated patients [AOR 0.16 (95\% $\mathrm{Cl}$ 0.33-0.82)]; whereas, inappropriate MUAC was not found to be significantly associated with the background characteristics (Table 3).

\section{Discussion}

A study on Socio-Demographic Factors Associated with Tuberculosis Cases Registered under RNTCP in an Urban Area of Pune, Maharashtra on 2018 showed that the proportions of male, female patients as $60 \%$ and $40 \%$ respectively and that of pulmonary and extra pulmonary groups as $62 \%$ and $38 \%$ respectively (7). The corresponding finding of sex distribution in this study was $74.3 \%$ and $25.7 \%$, whereas, $59.3 \%$ and $40.7 \%$ were suffering from pulmonary and extra pulmonary TB respectively. The present study however did not find any significant statistical association between the socioeconomic background characteristics and prevalence of under nutrition among the study participants which was 
similar to the finding observed by Gurung et al. on 2016 among 133 TB patients in Pokhara, Nepal (8).

In this present study, we found that majority (86.7\%) of the study participants were not having adequate total energy intake according to their respective age, gender and physical activity. Although, majority of the participants were having adequate protein $(72.6 \%)$ and $63.7 \%$ were having adequate fat intake, they were unable to meet their recommended total energy intake. This can be explained if we take a detailed look at their pattern of food intake in terms of different food groups. We found that cereals \& millets, milk \& milk products, fruits were deficient in most of the participants; whereas, sugar was deficient among moderate and heavy working participants and fat were deficient among moderate male and heavy workers (Table 2). TB patients had received counseling about improving food intake; this might also have increased their protein intake. However, further studies are required in this context as this study was not planned to evaluate this.

Scholars had argued that low body mass index (BMI) (lower than $18.5 \mathrm{~kg} / \mathrm{m}^{2}$ ) was associated with an increased risk of death (3) and TB relapse (9). According to the guidance document on nutritional care and support for patients with tuberculosis in India developed by Central TB division, Government of India published on 2016, under nutrition was observed in 55\% of annual TB incidence at population level in India (5). The present study found little higher prevalence of under nutrition, which may be due to different study sample (adult population) or study setting.

A study on nutritional assessment of newly diagnosed tuberculosis patients in a tertiary care hospital of Tripura, India reported $66 \%$ of the study population was having malnutrition (BMI $<18.5 \mathrm{~kg} / \mathrm{m} 2$ ) (10), This study showed similar findings with $61.2 \%$ of the subjects were having under-nutrition, but lower than the findings reported by a study on Nutritional Status of Adult Patients with Pulmonary Tuberculosis in Rural Central India (2004-19), which revealed that under-nutrition was present in more than $85 \%$ of rural men and women with pulmonary TB (11); the lower prevalence of under nutrition in the present study can be influenced by the different study settings.

As we know that MUAC is a better and reliable indicator of acute under nutrition more than BMI (12) as it is independent of height. The present study found that although $61.2 \%$ participants were having under nutrition, a little higher percentage of inappropriate MUAC was observed among them (68.1\%).

\section{Conclusion}

This study revealed that despite having adequate protein intake among two third of the study participants, total energy intake was alarmingly inadequate in majority of them due to inadequate intake of cereals \& millets, milk \& milk products and fruits among the different food groups. The prevalence of under nutrition was little higher when the MUAC criteria was applied than the BMI criteria and participants from new regimen were having lower odds of having under nutrition than previously treated regimen.

\section{Recommendation}

The patients with active form of TB are usually in energy deficient catabolic states and all of them should be counselled about consumption of a healthy balanced diet to achieve the desired energy and protein intake with three meals and three snacks, and promoting food hygiene and healthy cooking practices. This study also recommends that while assessing nutritional status of active TB patients, equal weightage should be given to BMI \& MUAC both the key indicators during diagnosis and also during their follow up.

\section{Limitation of the study}

While calculating the energy requirement of TB patients, this study utilised the guideline available from National Institute of Nutrition (NIN), India. The requirement is classified depending on the gender and physical activity of an individual. The requirement of a TB patient is likely to be more. As a result, the deficiency of food group intakes is likely to be under estimated in this study.

\section{Relevance of the study}

This study is one of the first in assessing the nutritional status of TB patients of India using dietary approach. It highlights the point that while counseling TB patients, health personnel should emphasise on intake of a balanced diet - utilising all the food groups in appropriate amount. It may be helpful to provide the patients a model diet chart, modified for the local foods available.

\section{Authors Contribution}

Conception and design of study: MA, SP, DDK, RS; Collection of data: MA; Data Analysis \& Interpretation: MA, RS; Manuscript preparation including drafting, editing \& review: $M A, S P, D D K, R S$.

\section{Acknowledgement}

The authors sincerely acknowledge the staffs of Tuberculosis unit in Burdwan municipality for their assistance and co-operation for conducting this study. The authors sincerely acknowledge and thank all the study participants for their active and supportive participation in this study.

\section{References}

1. Bhargava A, Benedetti A, Oxlade O, Pai M, Menzies D. Undernutrition and the incidence of tuberculosis in India: national and subnational estimates of the population-attributable fraction related to undernutrition. Natl Med J India. 2014 MayJun;27(3):128-33. PubMed PMID: 25668081. [PubMed].

2. Bhargava A, Chatterjee M, Jain $Y$, Chatterjee B, Kataria A, Bhargava M, Kataria R, D'Souza R, Jain R, Benedetti A, Pai M, Menzies D. Nutritional status of adult patients with pulmonary tuberculosis in rural central India and its association with mortality. PLoS One. 
INDIAN JOURNAL OF COMMUNITY HEALTH / VOL 32 / ISSUE NO 02 / APR - JUN 2020 2013;8(10):e77979. doi: 10.1371/journal.pone.0077979. eCollection 2013. PubMed PMID: 24205052; PubMed Central PMCID: PMC3812022.[PubMed].

3. Zachariah R, Spielmann MP, Harries AD, Salaniponi FM. Moderate to severe malnutrition in patients with tuberculosis is a risk factor associated with early death. Trans R Soc Trop Med Hyg. 2002 MayJun;96(3):291-4. doi: 10.1016/s0035-9203(02)90103-3. PubMed PMID: 12174782.[PubMed].

4. World Health Organization. Guideline: nutritional care and support for patients with tuberculosis. World Health Organization; 2013.p23.

5. Guidance Document- Nutritional Care \& Support for TB patients in India [Internet]. Central TB Division [Accessed on 28/03/2018]. Available from: http://www.tbcindia.gov.in/index1/.

6. Krishnaswamy K, Bhaskaram P, Bhat RV, Ghafoorunissa RT, Raghuramulu N, et al. Dietary guidelines for Indians: A manual. Hyderabad: National Institute of Nutrition, ICMR. 2011.p86.

7. Bhawalkar J, Khedkar D, Lanjewar B, Landge J, Ghonge S. SocioDemographic Factors Associated with Tuberculosis Cases Registered Under RNTCP in an Urban Area of Pune, Maharashtra. Natl J Community Medicine 2018;9(2):130-4.

8. Gurung LM, Bhatt LD, Karmacharya I, Yadav DK. Dietary Practice and Nutritional Status of Tuberculosis Patients in Pokhara: A Cross
[Nutritional status of...] | Mollah A et al Sectional Study. Front Nutr. 2018;5:63. doi: 10.3389/fnut.2018.00063. eCollection 2018. PubMed PMID: 30167434; PubMed Central PMCID: PMC6106647.[PubMed].

9. Khan A, Sterling TR, Reves R, Vernon A, Horsburgh CR. Lack of weight gain and relapse risk in a large tuberculosis treatment trial. Am J Respir Crit Care Med. 2006 Aug 1;174(3):344-8. doi: 10.1164/rccm.200511-18340C. Epub 2006 May 18. PubMed PMID: 16709935.[PubMed].

10. Das S, Sen S, Debnath A, Basuthakur S, Saha PK, Biswas C. A study of nutritional assessment of newly diagnosed tuberculosis patients in a tertiary care hospital of Tripura, India. Int J Res Med Sci 2018;6: 1382-7.

11. Bhargava A, Chatterjee $M$, Jain $Y$, Chatterjee $B$, Kataria A, Bhargava M, Kataria R, D'Souza R, Jain R, Benedetti A, Pai M, Menzies D. Nutritional status of adult patients with pulmonary tuberculosis in rural central India and its association with mortality. PLoS One. 2013;8(10):e77979. doi: 10.1371/journal.pone.0077979. eCollection 2013. PubMed PMID: 24205052; PubMed Central PMCID: PMC3812022.[PubMed].

12. United Nations/sub-committee on Nutrition, Geneva. Assessment of Nutritional status in Emergency-affected populations. Collins $\mathrm{S}$, Duffield A, Myatt M. UN; July, 2000.p8.

\section{Tables}

TABLE 1 DISTRIBUTION OF THE STUDY SUBJECTS ACCORDING TO BACKGROUND CHARACTERISTICS AND ANTHROPOMETRIC MEASUREMENTS ( $\mathrm{N}=113)$

\section{Background characteristics}

Age (completed years)

\begin{tabular}{|c|c|c|}
\hline \multicolumn{3}{|l|}{ Age (completed years) } \\
\hline $18-39$ & 54 & 47.7 \\
\hline $40-59$ & 43 & 38.1 \\
\hline$\geq 60$ & 16 & 14.2 \\
\hline \multicolumn{3}{|l|}{ Gender } \\
\hline Male & 84 & 74.3 \\
\hline Female & 29 & 25.7 \\
\hline \multicolumn{3}{|l|}{ Religion } \\
\hline Hinduism & 88 & 77.9 \\
\hline Islam & 25 & 22.1 \\
\hline \multicolumn{3}{|l|}{ Caste } \\
\hline General & 90 & 79.6 \\
\hline Other Backward Caste & 08 & 7.1 \\
\hline Scheduled Caste & 12 & 10.6 \\
\hline Scheduled Tribe & 03 & 2.7 \\
\hline \multicolumn{3}{|l|}{ Marital status } \\
\hline Currently married & 82 & 72.6 \\
\hline Unmarried/separated/widow \& widower & 31 & 27.4 \\
\hline \multicolumn{3}{|l|}{ Education } \\
\hline Illiterate/non-formal literate & 24 & 21.2 \\
\hline Less than primary completed & 25 & 22.1 \\
\hline Primary completed & 12 & 10.6 \\
\hline Middle school completed & 14 & 12.4 \\
\hline Secondary completed & 21 & 18.7 \\
\hline Higher secondary and above & 17 & 15.0 \\
\hline \multicolumn{3}{|l|}{ Occupation } \\
\hline Working & 80 & 70.8 \\
\hline Homemaker & 16 & 14.1 \\
\hline Retired/at home & 17 & 15.1 \\
\hline \multicolumn{3}{|l|}{ Type of worker } \\
\hline Sedentary & 63 & 55.8 \\
\hline
\end{tabular}

Frequency Percentage 
Moderate Heavy

Socio-economic status\#

\section{\#}

Upper class/upper middle

Middle

Lower middle

Lower

Type of TB
36

14

\begin{tabular}{l|r}
08 & 7.1
\end{tabular}

\begin{tabular}{|c|c}
\hline 12 & 10.6
\end{tabular}

55

38

67

46

Extra-pulmonary

Type of regimen

31.9

12.3

\begin{tabular}{l}
. \\
.6 \\
\hline
\end{tabular}

New

Previously treated
10.6

48.7

33.6

59.3

40.7

85.0

15.0

\section{Anthropometric variables}

BMI $\left(\mathrm{kg} / \mathrm{m}^{2}\right)$

Extremely underweight $(<14)$

96

17

Grade 3 underweight $(14<16)$

\begin{tabular}{|l|r|}
04 & 3.5 \\
\hline
\end{tabular}

Grade 2 underweight (16-16.9)

06

3.5

Grade 1 underweight (17-18.49)

25

22.1

31.0

Normal (18.5-22.9)

Overweight $(\geq 23)$

36.3

41

1.8

MUAC

\begin{tabular}{l|l}
\hline Appropriate* & 36 \\
\hline Inappropriate & 77
\end{tabular}

31.9

77

68.1

*MUAC $\geq 23 \mathrm{~cm}$ in Males and $\geq 22 \mathrm{~cm}$ in Females. \# modified B G Prasad scale (August, 2018)

TABLE 2 DISTRIBUTION OF THE STUDY SUBJECTS ACCORDING TO DIETARY INTAKE OF VARIOUS FOOD GROUPS WITH RESPECT TO GENDER AND WORK TYPE ( $N=113)$

\begin{tabular}{|c|c|c|c|c|c|c|c|}
\hline \multirow[t]{3}{*}{ Food Groups } & \multicolumn{6}{|c|}{ Type of work } & \multirow{3}{*}{$\begin{array}{l}\text { Overall } \\
\text { n (113) }\end{array}$} \\
\hline & \multicolumn{2}{|c|}{ Sedentary n (63) } & \multicolumn{2}{|c|}{ Moderate n (36) } & \multicolumn{2}{|c|}{ Heavy n (14) } & \\
\hline & $\begin{array}{l}\text { Male } \\
\mathrm{n}(\%)\end{array}$ & $\begin{array}{l}\text { Female } \\
\mathrm{n}(\%)\end{array}$ & $\begin{array}{l}\text { Male } \\
\text { n (\%) }\end{array}$ & $\begin{array}{l}\text { Female } \\
\mathrm{n}(\%)\end{array}$ & $\begin{array}{l}\text { Male } \\
\mathrm{n}(\%)\end{array}$ & $\begin{array}{l}\text { Female } \\
\mathrm{n}(\%)\end{array}$ & \\
\hline $\begin{array}{r}\text { Cereals \& millets } \\
\text { Adequate } \\
\text { Inadequate }\end{array}$ & $\begin{array}{l}00(00) \\
38(100)\end{array}$ & $\begin{array}{l}12(48) \\
13(52)\end{array}$ & $\begin{array}{l}05(14.2) \\
30(85.8)\end{array}$ & $\begin{array}{l}00(00) \\
01(100)\end{array}$ & $\begin{array}{l}00(00) \\
11(100)\end{array}$ & $\begin{array}{c}00(00) \\
03(100)\end{array}$ & $\begin{array}{l}17(15) \\
96(85)\end{array}$ \\
\hline $\begin{array}{l}\text { Pulses } \\
\text { Adequate } \\
\text { Inadequate }\end{array}$ & $\begin{array}{l}31(81.6) \\
07(18.4)\end{array}$ & $\begin{array}{l}25(100) \\
00(00)\end{array}$ & $\begin{array}{l}32(91.4) \\
03(8.6)\end{array}$ & $\begin{array}{l}01(100) \\
00(00)\end{array}$ & $\begin{array}{l}08(72.7) \\
03(27.3)\end{array}$ & $\begin{array}{l}02(66.7) \\
01(33.3)\end{array}$ & $\begin{array}{l}99(87.6) \\
14(12.4)\end{array}$ \\
\hline $\begin{array}{l}\text { Milk \& milk } \\
\text { products } \\
\text { Adequate } \\
\text { Inadequate }\end{array}$ & $\begin{array}{l}00(00) \\
38(100)\end{array}$ & $\begin{array}{l}01(4) \\
24(96)\end{array}$ & $\begin{array}{l}02(5.7) \\
33(94.3)\end{array}$ & $\begin{array}{l}00(00) \\
01(100)\end{array}$ & $\begin{array}{l}00(00) \\
11(100)\end{array}$ & $\begin{array}{l}00(00) \\
03(100)\end{array}$ & $\begin{array}{l}03(2.7) \\
110(97.3)\end{array}$ \\
\hline $\begin{array}{r}\text { Roots \& tubers } \\
\text { Adequate } \\
\text { Inadequate }\end{array}$ & $\begin{array}{l}37(97.4) \\
01(2.6)\end{array}$ & $\begin{array}{l}20(80) \\
05(20)\end{array}$ & $\begin{array}{l}34(97.1) \\
01(2.9)\end{array}$ & $\begin{array}{l}01(100) \\
00(00)\end{array}$ & $\begin{array}{l}11(100) \\
00(00)\end{array}$ & $\begin{array}{l}00(00) \\
03(100)\end{array}$ & $\begin{array}{l}103(91.1) \\
10(8.9)\end{array}$ \\
\hline $\begin{array}{l}\text { Green leafy } \\
\text { vegetables } \\
\text { Adequate } \\
\text { Inadequate }\end{array}$ & $\begin{array}{l}27(71.1) \\
11(28.9)\end{array}$ & $\begin{array}{l}21(84) \\
04(16)\end{array}$ & $\begin{array}{l}19(54.3) \\
16(45.7)\end{array}$ & $\begin{array}{l}01(100) \\
00(00)\end{array}$ & $\begin{array}{l}08(72.7) \\
03(27.3)\end{array}$ & $\begin{array}{l}02(66.7) \\
01(33.3)\end{array}$ & $\begin{array}{l}78(69) \\
35(31)\end{array}$ \\
\hline $\begin{array}{r}\text { Other vegetables } \\
\text { Adequate } \\
\text { Inadequate }\end{array}$ & $\begin{array}{l}22(57.9) \\
16(42.1)\end{array}$ & $\begin{array}{l}11(44) \\
14(56)\end{array}$ & $\begin{array}{l}20(57.1) \\
15(42.9)\end{array}$ & $\begin{array}{l}01(100) \\
00(00)\end{array}$ & $\begin{array}{l}04(36.4) \\
07(63.6)\end{array}$ & $\begin{array}{l}02(66.7) \\
01(33.3)\end{array}$ & $\begin{array}{l}60(53.1) \\
53(46.9)\end{array}$ \\
\hline $\begin{array}{l}\text { Adequate } \\
\text { Inadequate }\end{array}$ & $\begin{array}{l}06(15.8) \\
32(84.2)\end{array}$ & $\begin{array}{l}08(32) \\
17(68)\end{array}$ & $\begin{array}{l}09(25.7) \\
26(74.3)\end{array}$ & $\begin{array}{l}00(00) \\
01(100)\end{array}$ & $\begin{array}{l}03(27.3) \\
08(72.7)\end{array}$ & $\begin{array}{l}00(00) \\
03(100)\end{array}$ & $\begin{array}{l}26(23) \\
87(77)\end{array}$ \\
\hline
\end{tabular}




\begin{tabular}{|c|c|c|c|c|c|c|c|c|}
\hline Sugar & $\begin{array}{l}\text { Adequate } \\
\text { Inadequate }\end{array}$ & $\begin{array}{l}31(81.6) \\
07(18.4)\end{array}$ & $\begin{array}{l}18(72) \\
07(28)\end{array}$ & $\begin{array}{l}02(5.7) \\
33(94.3)\end{array}$ & $\begin{array}{l}00(00) \\
01(100)\end{array}$ & $\begin{array}{l}00(00) \\
11(100)\end{array}$ & $\begin{array}{l}00(00) \\
03(100)\end{array}$ & $\begin{array}{l}51(45.1) \\
62(54.9)\end{array}$ \\
\hline Fat & $\begin{array}{r}\text { Adequate } \\
\text { Inadequate }\end{array}$ & $\begin{array}{l}34(89.5) \\
04(10.5)\end{array}$ & $\begin{array}{l}25(100) \\
00(00)\end{array}$ & $\begin{array}{l}10(28.6) \\
25(71.4)\end{array}$ & $\begin{array}{l}01(100) \\
00(00)\end{array}$ & $\begin{array}{l}01(9.1) \\
10(90.9)\end{array}$ & $\begin{array}{l}01(33.3) \\
02(66.7)\end{array}$ & $\begin{array}{l}72(63.7) \\
41(36.3)\end{array}$ \\
\hline
\end{tabular}

TABLE 3 MULTIVARIABLE LOGISTIC REgRESSION ANALYSIS TO PREDICT UNDER-NUTRITION BY BACKGROUND CHARACTERISTICS ( $=113$ )

\begin{tabular}{|c|c|c|c|c|}
\hline \multirow{2}{*}{$\begin{array}{l}\text { Background characteristics } \\
\text { Age group (years) }\end{array}$} & \multicolumn{2}{|c|}{ Under-nutrition(BMI<18.5 kg/m2) } & \multicolumn{2}{|c|}{ Inappropriate MUAC* } \\
\hline & AOR & $(95 \% \mathrm{Cl})$ & AOR & (95\% Cl) \\
\hline $18-39$ & 0.48 & $(0.09-2.59)$ & 0.29 & $(0.53-1.69)$ \\
\hline $40-59$ & 0.34 & $(0.06-1.87)$ & 0.26 & $(0.04-1.55)$ \\
\hline$\geq 60$ & \multicolumn{4}{|c|}{ Reference } \\
\hline \multicolumn{5}{|l|}{ Gender } \\
\hline Male & 0.69 & $(0.10-4.51)$ & 1.49 & $(0.26-8.41)$ \\
\hline Female & \multicolumn{4}{|c|}{ Reference } \\
\hline \multicolumn{5}{|l|}{ Religion } \\
\hline Hinduism & 0.79 & $(0.27-2.31)$ & 1.14 & $(0.39-3.29)$ \\
\hline Islam & \multicolumn{4}{|c|}{ Reference } \\
\hline \multicolumn{5}{|l|}{ Occupation } \\
\hline Working & 0.87 & $(0.13-5.54)$ & 2.15 & $(0.34-13.36)$ \\
\hline Homemaker & 0.19 & $(0.03-1.23)$ & 0.85 & $(0.14-4.90)$ \\
\hline Retired/at home & \multicolumn{4}{|c|}{ Reference } \\
\hline \multicolumn{5}{|l|}{ Socio-economic status ${ }^{\#}$} \\
\hline Upper class/upper middle & 0.26 & $(0.04-1.46)$ & 0.29 & $(0.56-1.53)$ \\
\hline Middle & 0.92 & $(0.22-3.77)$ & 0.83 & $(0.19-3.65)$ \\
\hline Lower middle & 0.82 & $(0.31-2.18)$ & 0.86 & $(0.31-2.38)$ \\
\hline Lower middle & \multicolumn{4}{|c|}{ Reference } \\
\hline \multicolumn{5}{|l|}{ Type of regimen } \\
\hline New & 0.16 & $(0.33-0.82)$ & 0.28 & $(0.05-1.43)$ \\
\hline Previously treated & \multicolumn{4}{|c|}{ Reference } \\
\hline Nagelkerke $\mathbf{R}^{2}$ & \multicolumn{2}{|c|}{0.191} & \multicolumn{2}{|c|}{0.159} \\
\hline $\begin{array}{l}\text { Hosmer Lemeshow test } \\
\text { p value }\end{array}$ & \multicolumn{2}{|c|}{0.474} & \multicolumn{2}{|c|}{0.819} \\
\hline
\end{tabular}

